\title{
Reducing the Drop of Budget Revenues as a Factor of Sustainable Development of the Region
}

\author{
Natalia Valeryevna Gorshkova \\ Volgograd State University, \\ Institute of Economics and Finance \\ Volgograd, Russia \\ GorshkovaNV@volsu.ru
}

\author{
Alexander Vladimirovich Dorzdeev \\ Volgograd State University, \\ Institute of Economics and Finance \\ Volgograd, Russia \\ dorzhdeev_av@volsu.ru
}

\author{
Victoria Mikhailovna Ksenda \\ Volgograd State University, \\ Institute of Economics and Finance \\ Volgograd, Russia \\ KsendaVM@volsu.ru
}

\begin{abstract}
The formation of all level budgets is provided to a greater extent by tax revenues of which the justified distribution is the effective functioning basis of the budget system. The Russian model of tax revenue distribution has the following features: First is delineation of powers to the taxes collection and fixing them for certain taxes. Second is the normative division between budgets of different levels of income from specific types of taxes levied at uniform rates throughout the territory. Third is joint use of the tax base. Thus, the current mechanism for generating revenues of Regional and local budgets directly depends on the decisions made by the higher budget level, since their volume depends on the size of types of taxes transferred and the allocations norms to the respective budgets. The analysis of tax revenues has made it possible to identify the problems of Regional budgets formation. Thus, the joint use of corporate profit tax bases and the ability of federal center to influence the change in such an element as the tax rates has had a significant impact on regional budgets' revenues. In addition, the functioning of consolidated groups of taxpayers in calculating the corporate income tax resulted in significant losses in regional budgets' revenues. All the above facts, as well as the provision of other preferences for taxpayers, form budget losses in the falling income form. The study which has been made gives us a possibility to formulate concrete proposals for reducing such falling revenues of regional budgets, in particular, by improving the budget and tax legislation.
\end{abstract}

Keywords - budgetary system, tax revenues, tax preferences, corporate income tax, falling budget revenues, consolidated group of taxpayers

\section{INTRODUCTION}

Competitive and sustainable development of regional economy in the modern global transformations' conditions is impossible without the stable financial bases existence which are quality budgets of all levels. The main sources of budgetary resources are tax and non-tax revenues. The budget system specifics and budgetary and fiscal powers content enshrined in federal legislation, as well as the main the state budget and tax policy directions, indicate that the distribution practice of tax revenue between the Russian Federation, subjects of the Russian Federation and municipalities, which leads to an imbalance of interbudgetary relations due to high revenue centralization in the federal budget and budgetary sweat (falling tax revenues) in the subfederal budgets.

The reason for the falling income problem emergence is tax preferences for regional and local taxes provision, especially at the federal level. In our opinion, the problem solution is possible through redistribution of tax authorities and improvement of tax legislation.

To study the problem of delineation of budgetary-fiscal powers and falling incomes, the results of national scientific researches such as F.F. Adigamova, M.E. Orlova [1]; A.M. Baltina, N.V. Pivovarova [2]; K.A. Bannova, I.N. Dolgikh, N.A. Kuzmina [3]; L.S. Grinkevich [4]; E.B. Dyakova, I.A. Sushkova [5]; L.L. Igonina, I.V. Mamonov [6]; N.I. Malis [7]; L.Y. Marshavina [8]; H.M. Musaeva, K.M. Abdullaeva [9]; I.Y. Nesterenko [10]; M.R. Pinskaya, G.V. Kolesnik [11]; T.A. Troyanskaya, E.A. Ermakova [12] are analyzed. 


\section{MATERIALS AND METHODS (MODEL)}

General scientific methods of research were used during performing scientific research such as observation, analysis, synthesis, generalization, induction, deduction, analogy, comparison. Also private ones, such as expert assessments and correlation analysis. Data from Federal State Statistics Service (Rosstat), Federal Tax Service (FTS of Russia) statistical tax reporting forms, Accounts Chamber of the Russian Federation reports and other departmental information was used.

\section{RESULTS AND DISCUSSION}

Tax revenues are the main source of income of all level budgets of the Russian Federation. According to Federal Tax Service of Russia [13] the oil price decrease background in 2015 by $48 \%$ (from 97.7 to $51.2 \$$ / barrel) and in 2016 by $19 \%$ (to $41.7 \$$ / barrel), as well as economy negative growth rates (the growth of gross domestic product (GDP) in 2015 was $97.2 \%$, in $2016-99.8 \%$ ), tax revenues to the consolidated budget grew, in 2015, the revenues growth rate was $108.8 \%$, in 2016 it was $105 \%$. At the same time, the share of oil and gas revenues in tax revenue structure declined; in 2015 they amounted as $23 \%$, in 2016 as $20 \%$. In 2016 , there was a steady increase in tax revenues due to increase of share of valueadded tax (VAT) by $8.5 \%$ and to corporate profit tax by $6.6 \%$ and also personal income tax by $7.5 \%$, which allowed to fully compensate the reduction of mineral extraction tax (MET) by $9.2 \%$, or almost 300 billion rubles.

According to the Accounts Chamber of the Russian Federation [14], the share of tax revenues to total volume of federal budget revenues from January to September 2017 were $73.6 \%$, which is $4.7 \%$ higher than from January to September $2016(68.9 \%$ ). From January to September 2017, VAT and MET were $82.6 \%$, which amounted as $46.9 \%$ and $35.7 \%$ in structure of tax revenues, respectively.

Besides, revenues to consolidated regional budgets from January to August 2017 increased by 549.5 billion rubles, or by $8.7 \%$, as compared to the corresponding period of 2016 . At the same time, 15 regions of the Russian Federation decreased incomes especially there was a significant decrease in Sakhalin Region (by 25.7\%), the Republic of Ingushetia (by $16.6 \%$ ), the Kabardino-Balkarian Republic (11.2\%), KhantyMansiysk Region (by 13.9\%), Chukotka Autonomous District (by $9.3 \%$ ), Tomsk Region (by 7.8\%), Jewish Autonomous Region (by 7.7\%), Novgorod Region (by 6.7\%).

The structure of tax revenues hasn't changed in recent years. The largest share belongs to corporate income tax (25.5\% of total revenue) and personal income tax $(29.5 \%)$. Incomes from property taxes group don't significantly affect the revenues of consolidated budgets of regions of the Russian Federation. Their share is only $11.5 \%$.

Income from personal income tax from January to August 2017 , compared to the same period in 2016, increased by $8.2 \%$ and amounted as 2028.8 billion rubles (growth rate from January to August 2016 was $107.4 \%$ ). The growth of personal income tax was mainly due to the increase of nominal average monthly salary (according to Rosstat [15] it was $107.2 \%$ compared with the corresponding period of 2016). At the same time, the real average monthly gross salary was $102.9 \%$ compared to the same period of 2016.

The decrease of personal income tax compared to the same period of 2016 is noted in Tambov Region (by 28.2\%), the Karachay-Cherkess Republic (4.4\%), the Chechen Republic (3.5\%), the Komi Republic $(0.6 \% \%)$ and Nenets Autonomous District (by 0.2\%). For example, in Tambov Region the decrease was 2581.3 million rubles due to largest agricultural holdings income tax transfer of 2,870.3 million rubles in 2016 by beneficiaries.

Revenues from corporate income tax in 2017 increased by 166.1 billion rubles, or by $9.1 \%$, compared to the corresponding period of 2016 (in the corresponding period of 2016 the rate of growth was $105.8 \%$ ). The positive growth was provided mainly by the establishment of restrictions on losses of previous years transfer to the current period profit from January 1, 2017.

At the same time there was a decrease of this tax revenues in 23 regions, mainly in Khanty-Mansiysk Autonomous District (growth rate was only 51.8\%), Chukotka Autonomous District (53.6\%), Sakhalin Region (54.8\%), Tomsk Region (58.3\%), the Republic of Sakha (Yakutia) (58.4\%), Novgorod Region (74.9\%). In Khanty-Mansiysk Autonomous District the corporate income tax decrease was due to the centralization of $1 \%$ tax rate to the federal budget, also it was due to the largest taxpayer's loss gained from the exchange rate differences on foreign currency obligations, and also the overpaid tax return.

Volgograd Region, Murmansk Region, Rostov Region, Ulyanovsk Region, Khanty-Mansiysk Autonomous District were also subjects of the Russian Federation which also noted the negative impact of tax legislation changes with regard to the corporate income tax rate reduction credited to the budgets of the constituent entities of the Russian Federation from $18 \%$ to $17 \%$ of $20 \%$ tax rate established by law.

In Sakhalin Region the decrease of income tax paid by organizations under the Sakhalin-1 and Sakhalin-2 production sharing agreements was affected by the decrease in dollar terms tax base due to reduction of oil and gas prices and decrease of ruble to US dollar. In addition profit tax rate under the production sharing agreements (Sakhalin-2 project) has dropped from $80 \%$ to $75 \%$, which has reduced the revenues of Sakhalin Region budget by 2.4 billion rubles in 2017 .

The volume of income tax of organizations of the Republic of Sakha (Yakutia) was affected by presence of overpayments for this tax related to negative exchange rate differences due to a change in the official exchange rate of foreign currency included in non-operating expenses. As of September 1, 2017, the amount of overpayment for corporate profit tax was 2,868.8 million rubles, of which 116.7 million rubles were of consolidated taxpayer groups participants.

In addition, significant amounts of refunds (offset against current payments) continue to influence the receipt of corporate income tax in connection with organizations of tax declarations submission "to decrease the base" which is 
recorded in the Republic of Karelia, the Udmurt Republic, Leningrad, Smolensk and Ulyanovsk Regions.

As the statistics of the Russian Federation show, significant tax revenues portion of federal budget are from VAT and MET. The corporate profit tax share in federal budget structure of revenues is about $6 \%$, and of regional budget revenues is over $25 \%$. Thus, corporate income tax and personal income tax related to federal taxes are the most significant sources for the regional budgets formation, and limited fiscal powers, expressed in the impossibility of regions to influence the changes in tax elements (tax rate, tax incentives) and deduction rates (as happened in 2017 as a result of deductions transfer from $2 \%$ to $3 \%$ of the profit tax to federal level and a reduction in the share of write-off losses) lead to budgetary losses which are falling incomes (tax expenses).

Analyzing and summarizing the studies on the prerequisites and factors of budget losses emergence, the conclusion was made that the budget losses in the form of falling income (tax expenditures) should be understood as unreceived budget income as a result of taxpayers' preferences application provided by the legislation on taxes and fees. As noted by F.F. Adigamova and M.E. Orlov [1], the term "tax preferences" is not used in Russian tax legislation, but the terms "exemption" are applied to subject of taxation (articles 145, 145.1 of the Tax Code of the Russian Federation) and object of taxation (articles 149, 217, 251), "tax relief" (articles 333.35, 333.36, 333.37, 333.38, 333.39, 381, 395, 407), "tax deductions" (articles 218, 219,219.1, 220, 221), "procedure for payment of taxes time limits changing" (articles 63-68). The tax legislation also offers preferences in the form of lowering tax rates (articles 284284.1 of the Tax Code of the Russian Federation), the possibility of increasing expenses when calculating the corporate income tax (articles 257, 258, 259.1, 259.2 of the Tax Code). Tax preferences can be granted by laws of the constituent entities of the Russian Federation as on corporate profit tax, corporate property tax, transport tax, on tax levied in connection with the application of a simplified taxation system, on the patent taxation system; decisions of representative bodies of municipalities: on the tax on property of individuals, on land tax. Thus, the authorities of the subfederal level do not have the right to influence the regulatory elements of federal taxes, but they have the right to introduce preferences in respect to regional and local taxes, but taking into account the limiting restrictions established by federal tax legislation. According to calculations of I.Y. Nesterenko [10] the most significant tax expenses are formed on the corporate profit tax, value added tax, taxes on mining, and on property of organizations.

Russia is a state with a federal structure, divided into 8 federal districts. As part of the Russian Federation, 85 equal subjects of the federation, including 22 republics, 9 territories, 46 regions, 3 cities of federal significance, 1 autonomous region, 4 autonomous districts. Subjects of the federation have their own administrative-territorial division. As a rule, the main administrative-territorial units within the constituent entity of the federation are the regions and cities of regional (republican, regional, and district) significance. The development of the subjects of the Russian Federation is not uniform, because it depends on various factors: natural and climatic, socio-economic, political, ethno-demographic, etc.

The Southern Federal District (SFD) is located in the south of the European part of Russia, which includes the Republic of Adygea, Astrakhan Region, Volgograd Region, the Republic of Kalmykia, Krasnodar Territory, the Republic of Crimea, Rostov Region, and Sevastopol. The administrative center is Rostov-on-Don. According to Rosstat [16], the population is $16,428,458$ (almost $11.19 \%$ of the Russian population), of which the economically active population is $6,951,600$ people, which is more than $9 \%$ of the economically active population of Russia, with the bulk accounted for the share of the Krasnodar Territory and the Rostov Region.

The subjects' budgets revenues of the Southern Federal District have shown positive dynamics and different levels of income (table I) over the past few years.

\section{TABLE I. SUBJECTS' BUDGETS INCOMES OF THE SFD} IN 2015-2016, MILLIONS RUBLES.

\begin{tabular}{|c|c|c|c|}
\hline $\begin{array}{c}\text { Subject of the Russian } \\
\text { Federation }\end{array}$ & 2015 & 2016 & $\begin{array}{c}\text { Deviations, } \\
\%\end{array}$ \\
\hline Astrakhan Region & 38626,94 & 38863,55 & 100.6 \\
\hline Volgograd Region & 100282,94 & 101485,97 & 101.1 \\
\hline Sevastopol & 21244,46 & 21818,39 & 102.7 \\
\hline Krasnodar Terriotory & 236840,63 & 263308,45 & 111.2 \\
\hline Republic of Adygea & 17004,66 & 18113,53 & 106.5 \\
\hline Republic of Kalmykia & 11257,49 & 11637,07 & 103.4 \\
\hline Republic of Crimea & 95766,58 & 116745,62 & 121.9 \\
\hline Rostov Region & 170793,40 & 190895,13 & 111.8 \\
\hline
\end{tabular}

a. Compiled by the authors according to Volgograd Region Finance Committee data [17]

Volgograd Region consolidated budget revenues also show positive dynamics including both tax and non-tax incomes (table II). Volgograd region consolidated budget tax revenues structure confirms the previous conclusion that the main sources of regional budgets tax revenues are personal income tax and corporate income tax.

TABLE II. IMPLEMENTATION OF CONSOLIDATED BUDGET OF VOLGOGRAD REGION IN 2015-2016, THOUSAND RUBLES

\begin{tabular}{|c|c|c|c|}
\hline Index & 2015 & 2016 & $\begin{array}{c}\text { Deviations, } \\
\%\end{array}$ \\
\hline Incomes & 100282930 & 101485789 & 101.2 \\
\hline of which are taxes: & & & 99.6 \\
\hline corporate income tax & 19487985 & 19420652 & 107.7 \\
\hline personal income tax & 27219053 & 29326722 & 118.7 \\
\hline excises & 7869429 & 9342569 & 116.6 \\
\hline simplified taxation system & 2994365 & 3491229 & 92.3 \\
\hline tax on imputed income & 1280558 & 1182345 & 177.6 \\
\hline unified agricultural tax & 161333 & 286517 & 128.7 \\
\hline personal property tax & 429118 & 552431 & 103.5 \\
\hline corporate property tax & 6758081 & 6998470 & 108.2 \\
\hline transport tax & 1499494 & 1621842 & 74.7 \\
\hline land tax & 3638288 & 2719126 & 163.3 \\
\hline tax on extraction of & 39843 & 65065 & 109.8 \\
\hline minerals & & & 103.6 \\
\hline other tax revenues & 543213 & 596457 & 88.1 \\
\hline Non-tax & 5733656 & 5941024 & 100.5 \\
\hline Gratuitous receipts & 22628514 & 19941342 & 94.7 \\
\hline Costs & 107518971 & 108067234 & \\
\hline Surplus (+) / deficit (-) & -7236042 & -6581444 & \\
\hline
\end{tabular}

b. Compiled by the authors according to the data of the Finance Committee of Volgograd Region [17] 


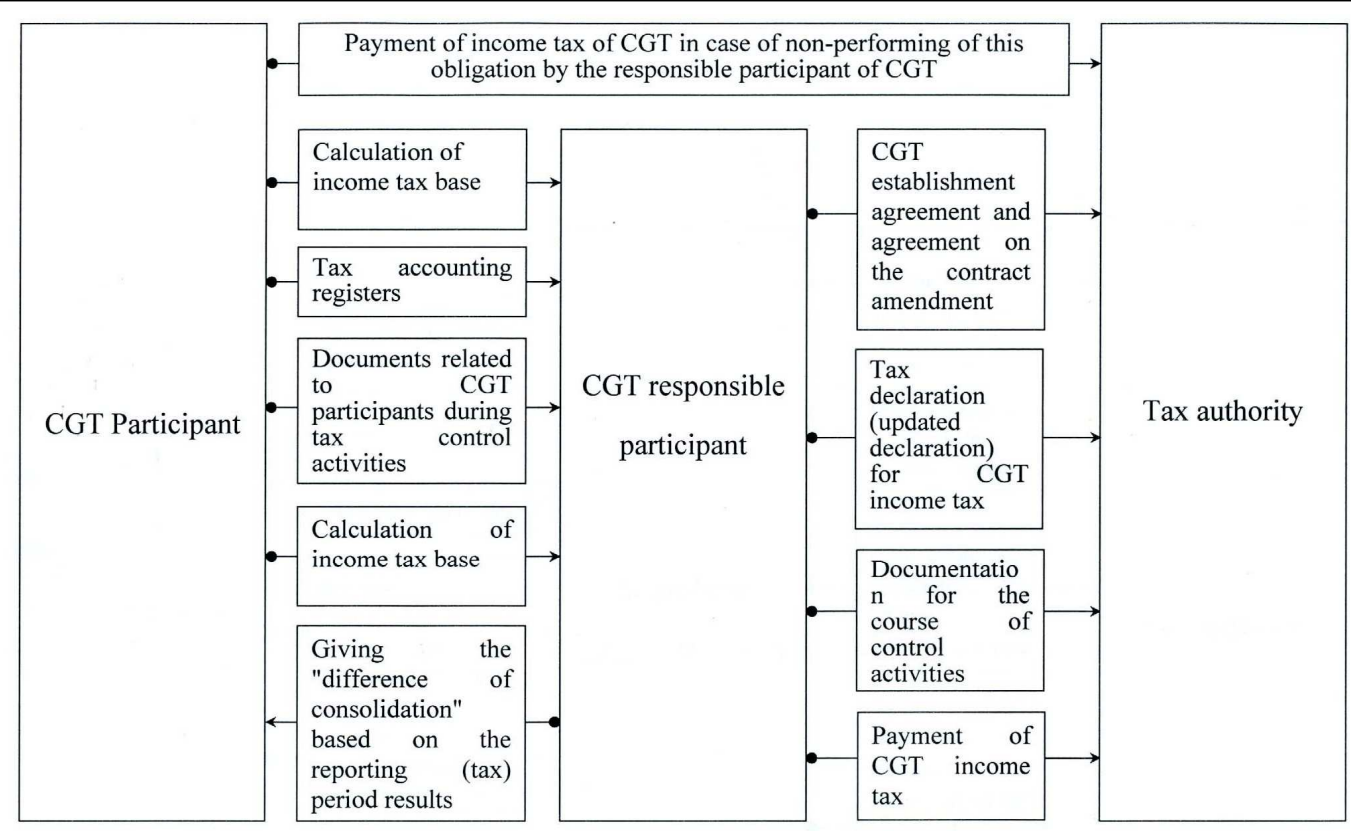

Fig. 1 Scheme of interaction of participants of the consolidated group of taxpayers in the process of profit taxation

However, according to Volgograd Region Finance Committee [17], for several years there were factors that have a negative impact on revenue formation of Volgograd Region consolidated budget:

- tax privileges established by federal legislation on regional and local taxes.

According to 2016 results the budget losses of Volgograd Region from the federal tax privileges granted at the federal level amounted 2982.0 million rubles, including 2170.6 million rubles for regional taxes and 811.4 million rubles for local taxes. At the same time, falling revenues total amount from provision to Volgograd Region consolidated budget in 2016 amounted 5571.6 million rubles, which is $60.9 \%$ higher than in the previous year (in 2015 - 3463.4 million rubles:

- taxpayer's right to refund the overpaid tax amount for three years from the date of payment.

In 2016 taxpayers filed tax returns for reimbursement from Volgograd Region budget for organizations' profit tax for a total amount of 5.5 billion rubles:

- income tax payment under the agreement on creation of consolidated groups of taxpayers.

As a result of institution of consolidated groups of taxpayers' establishment the budget of Volgograd Region bears annual losses of about 3 billion rubles. Uncompensated losses of budget of Volgograd Region in connection with creation of consolidated groups of taxpayers for period of 2012-2016 amounted as 12.6 billion rubles.

H.M. Musaeva, K.M. Abdullayeva [9] noted that the concept of a "consolidated taxpayer" is not new for tax systems of foreign countries.
First time this subject was legally established in the early 20th century in Austria, and nowadays it is widely used in the United States, Britain, Germany, France, Spain, Holland, Norway, Sweden and other countries. At its core, the consolidated reporting institution in developed countries is an instrument of tax planning, which allows to create favorable conditions for the development of business and economy on the whole. The tax model for CGT in Russia is borrowed from Germany and France, where organizations consolidation occurs under the income tax.

Consolidated group of taxpayers is a voluntary association of Russian organizations that pay corporate profit tax on the basis of an agreement on such a group creation. The conditions for the creation of CGT are:

- One company directly and (or) indirectly participates in the authorized capital of other organizations and the share of participation in each such legal entity is at least $90 \%$;

- Total paid VAT / excise / income tax / MET is amounted $\geq 10$ billion rubles;

- Total revenue from sales of goods, products, works, services, as well as from other incomes of all participants of CGT $\geq 100$ billion rubles;

- The aggregated assets value of all participants of the group as of December 31 is $\geq 300$ billion rubles.

The participants' interaction in the consolidated group of taxpayers in calculating and paying income tax is presented on fig. 1 . 


\begin{tabular}{|c|c|}
\hline CGT Participants & Consolidated group of taxpayers \\
\hline $\begin{array}{l}\text { 1. Incomes and expenses forming a tax base, } \\
\text { taxable at a rate of } 20 \% \text {. } \\
\text { Participant number } 1 \text { which received profit }+ \\
\text { Participant number } 2 \text { which received losses }- \\
\text { Participant number } 3 \text { which received profit }+ \\
\text { 2. Tax base which is taxed at different rates than } \\
20 \% \text {. } \\
\text { 3. Tax base determined by the tax agent. }\end{array}$ & $\begin{array}{l}\text { Consolidated group of taxpayers, } \\
\text { taxable at a rate of } 20 \% \text {. } \\
\text { Incomes minus costs of all participants } \\
\text { Features of consolidated tax base formation: } \\
\text { - In the provision for doubtful debts, the debt } \\
\text { betwecn the participants is not taken into } \\
\text { account. } \\
\text { - In the provision for warranty repair and } \\
\text { maintenance does not take into account funds } \\
\text { between the participants } \\
\text { - The tax base does not decrease for losses } \\
\text { incurred before entering the CGT. }\end{array}$ \\
\hline \multicolumn{2}{|c|}{$\begin{array}{l}\text { Calculation of profit share }\left(d_{i}\right) \text { of a CGT participant for purposes of calculating the corporate income tax: } \\
\qquad \frac{A E_{i}}{\sum_{i=1}^{N} A E_{i}}+\frac{R V_{i}}{\sum_{i=1}^{N} R V_{i}}\end{array}$} \\
\hline $\begin{array}{l}d_{i} \text { - share of profit for } i \text { participant of CGT, \%; } \\
N-\text { number of participants of CGT; } \\
A E_{i} \text { - the average number of employees (labor costs) of } i \text { participa } \\
R V_{i} \text { - residual value of depreciable property of } i \text { participant of CG }\end{array}$ & \\
\hline
\end{tabular}

Fig. 2 Features of formation of tax base of the consolidated group of taxpayers

Tax authorities of the Russian Federation have 16 consolidated groups of taxpayers registered by now. Basically, the association of large taxpayers into groups occurred in the oil and gas sector, metallurgy and communications. Our analysis of statistics of the Federal Tax Service of Russia [13] shows that by 2017 number of CGT participants has almost doubled from 1707 units in 2012 to 2886 units in 2017. However the amount of CGT has changed insignificantly in 2015-2016. This is explained by the fact that agreements registered by tax authorities during 2014 took effect on January 1, 2016, which meant the introduction of a moratorium on the creation and amendment of the CGT contracts.

The restriction on amendment of CGT contracts is caused by the fact that the Federal Tax Service of Russia [13] and the Accounts Chamber of the Russian Federation [14] carried out an analysis of administration effectiveness of income tax payment by consolidated groups of taxpayers for 2012-2013. Following the results of the implementation of these activities, the following conclusions were made [15]. In 2012 the consolidated budget of the Russian Federation received an income tax of 2.4 trillion rubles, or $103.7 \%$ of revenue level in 2011 , and in $2013-2.1$ trillion rubles, or $88 \%$ of level of 2012. At the same time, taxpayers who are part of CGT paid 348.2 billion rubles in consolidated regional budgets in 2013, which is 145.7 billion rubles, or $29.5 \%$ less than in 2012 . In 2013 income tax revenues of CGT organizations increased in 62 regions, including 17 where they were more than 1 billion rubles. In 20 regions, revenues decreased, 11 of which were more than 1 billion rubles including Moscow, St. Petersburg, Krasnoyarsk, Perm, Belgorod, Tyumen, Volgograd, Nizhny Novgorod and Samara Regions, the Republic of Karelia and
Khanty-Mansi Autonomous Area. In this regard, the Accounts Chamber of the Russian Federation has offered the government to allocate funds to regions with a low level of budgetary provision with significant losses from the action of CGT: Belgorod, Volgograd, Nizhny Novgorod and Samara regions, Perm Krai and Karelia.

As noted by M.A. Troyanskaya and E.A. Ermakova [12], regions' differentiation by the introduction effect of tax consolidation testifies the problem of redistribution of tax potential between regions. There is a "migration" of tax base and tax revenues to administratively strong subjects of the Federation. The distribution of profit between the participants of CGT depends not on their financial results, but on the average number of employees (or labor costs) and the residual value of depreciable property (fig. 2). This contributes the largest companies to pay profit tax in those regions where production capacities and personnel are concentrated and, on the contrary, leads to a decrease in income tax receipts in regions of parent companies registration (such cities as Moscow and St. Petersburg).

\section{CONCLUSION}

Thus, the analysis of regions of the Russian Federation consolidated budgets' tax revenues' dynamics and structure showed that more than half of revenues depend on corporate profit tax and personal income tax which are federal taxes, and its regulation is the prerogative of federal center. As a result, regional governments lose control over the tax base management. Granting federal privileges on regional taxes entails budgetary losses in the form of falling out incomes. 
To solve the identified problems, there are proposals:

- to consider the integrated approach issue to the provision of tax benefits through a system of tax and non-tax expenses. So, with regard to benefits established by regional legislation, it is advisable to establish a period during which preferential taxation will operate;

- to review the procedure of determining the aggregate taxable profit of CGT, namely, the profit share of each participant of the group and each separate division of the group's aggregate profits to be determined on the basis of the profit share of "profitable" participants of CGT in the aggregate profit of "profitable" CGTs;

- to shorten the period during which the taxpayer can file an application for the offset or return the overpaid tax amount of on the profit of organizations up to 1 year. Currently, it is for 3 years from the date of tax payment, which leads to formation of a significant amount to be returned. Taking into account that corporate income tax is one of the main budgetforming incomes of constituent entities of the Russian Federation, a lump-sum return of significant amounts of income tax, especially for participants of CGT, adversely affects the ability to finance budget expenditures;

- before adopting amendments to the legislation of the Russian Federation on taxes and fees, provide a mechanism for budget legislation compulsory compensation of budgets' falling revenues in connection with the establishment of CGT.

\section{References}

[1] F.F. Adigamova, M.E. Orlova. "Theoretical and practical aspects of tax preferences”. Innovative development of the economy. 2016. № 3-2 (33). pp. 49-54. [F.F. Adigamova, M.E. Orlova. Teoreticheskie i prakticheskie aspekty nalogovykh preferentsii // Innovatsionnoe razvitie ekonomiki. - 2016. - № 3-2 (33). - S.49-54].

[2] A.M. Baltina, N.V. Pivovarova. "Reflection of tax expenses and subsidies in budget reporting". Modern problems of science and education. 2015. № 2-3. pp. 115. [A.M. Baltina, N.V. Pivovarova. Otrazhenie nalogovykh raskhodov i subsidii v otchetnosti po byudzhetu // Sovremennye problemy nauki i obrazovaniya. - 2015. - № 2-3. - S. 115].

[3] K.A. Bannova, I.N. Dolgikh, N.A. Kuzmina. "Perfection of the method of distribution of tax revenues of Regions from the consolidated group of taxpayers on the basis of added value". Finances and credit. 2016. № 3 (675). pp. 29-39. [K.A. Bannova, I.N. Dolgikh, N.A. Kuz'mina. Sovershenstvovanie metodiki raspredeleniya nalogovykh dokhodov Regionov ot konsolidirovannoi gruppy nalogoplatel'shchikov na osnove dobavlennoi stoimosti // Finansy i kredit. - 2016. - № 3 (675). - S. 2939].

[4] L.S. Grinkevich. "Consolidated group of taxpayers as a tool for fair distribution of tax income”. Finance. 2015. №. 2. pp. 40-44. [L.S.
Grinkevich. Konsolidirovannaya gruppa nalogoplatel'shchikov kak instrument spravedlivogo raspredeleniya nalogovykh dokhodov // Finansy. - 2015. - № 2. - S. 40-44].

[5] E.B. Dyakova, I.A. Sushkova. "Tax system of the Russian Federation in the conditions of budgetary federalism”. Finance and credit. 2011. № 7 (439). pp. 55-63. [E.B. D'yakova, I.A. Sushkova. Nalogovaya sistema Rossiiskoi Federatsii v usloviyakh byudzhetnogo federalizma // Finansy i kredit. - 2011. - № 7 (439). - S. 55-63].

[6] L.L. Igonina, I.V. Mamonova. "Stimulating tax benefits as an instrument of fiscal regulation: application features and effectiveness evaluation at the Regional level". Financial analytics: problems and solutions. 2016. № 37 (319). pp. 45-60. [L.L. Igonina, I.V. Mamonova. Stimuliruyushchie nalogovye l'goty kak instrument byudzhetnonalogovogo regulirovaniya: osobennosti primeneniya $i$ otsenka effektivnosti na regional'nom urovne // Finansovaya analitika: problemy i resheniya. - 2016. - № 37 (319). - S. 45-60].

[7] N.I. Malis. "Reserves of growth of tax incomes of regions". Taxes and the finance. 2015. № 1 (25). pp. 28-34. [N.I. Malis. Rezervy rosta nalogovykh dokhodov Regionov // Nalogi i finansy. - 2015. - № 1 (25). - S. 28-34]

[8] L.Ya. Marshavina. "Taxes in the system of interbudgetary relations", Finance and credit. 2012. № 15. pp. 5-10. [L. Ya. Marshavina. Nalogi v sisteme mezhbyudzhetnykh otnoshenii // Finansy i kredit. - 2012. - № 15. - S. 5-10].

[9] H.M. Musaeva, K.M. Abdullayeva. "The Institute of the consolidated group of taxpayers in the Russian Federation: assessment and problems of functioning”. Fundamental research. 2016. № 11-4. pp. 839-845. [Kh.M. Musaeva, K.M. Abdullaeva. Institut konsolidirovannoi gruppy nalogoplatel'shchikov $\mathrm{v}$ Rossiiskoi Federatsii: otsenka i problemy funktsionirovaniya // Fundamental'nye issledovaniya. - 2016. - № 11-4. - S. 839-845].

[10] I.Y. Nesterenko. "Regional tax benefits: best practices and economic evaluation”. Finance and credit. 2015. № 1 (625). pp. 29-39. [I.Yu. Nesterenko. Regional'nye nalogovy l'goty: praktika primeneniya i ekonomicheskaya otsenka // Finansy i kredit. - 2015. - № 1 (625). S.29-39].

[11] M.R. Pinskaya, G.V. Kolesnik. "Delimitation of powers between the federal and Regional levels of government in the field of tax benefits: fiscal consequences". Economics and mathematical methods. 2016. Vol. 52. № 3. pp. 22-35. [M.R. Pinskaya, G.V. Kolesnik. Razgranichenie polnomochii mezhdu federal'nym i regional'nym urovnem vlasti $\mathrm{v}$ oblasti nalogovykh l'got: fiskal'nye posledstviya // Ekonomika i matematicheskie metody. - 2016. - T.52. - № 3. - S. 22-35].

[12] M.A. Troyanskaya, E.A. Ermakova. "Consolidated group of taxpayers: the combination of interests of state and taxpayers". Economic revival of Russia. 2015. № 1 (43). pp. 56-64. [M.A. Troyanskaya, E.A. Ermakova. Konsolidirovannaya gruppa nalogoplatel'shchikov: sochetanie interesov gosudarstva i nalogoplatel'shchikov // Ekonomicheskoe vozrozhdenie Rossii. - 2015. - № 1 (43). - S. 56-64].

[13] Federal Tax Service. URL: https://www.nalog.ru [Federal'naya nalogovaya sluzhba. URL: https://www.nalog.ru].

[14] Accounts chamber of the Russian Federation. URL: http://www.ach.gov.ru/ [Schetnaya palata Rossiiskoi Federatsii. URL: http://www.ach.gov.ru/].

[15] Accounting. Taxes. Audit.URL: https://www.audit-it.ru/ [Bukhgalterskii uchet. Nalogi. Audit. URL: https://www.audit-it.ru].

[16] Federal State Statistics Service. URL: http://www.gks.ru/. [Federal'naya sluzhba gosudarstvennoi statistiki. URL: http://www.gks.ru/].

[17] The Finance Committee of the Volgograd Region. URL: http://volgafin.volgograd.ru/ [Komitet finansov Volgogradskoi oblasti. URL: http://volgafin.volgograd.ru/]. 